\title{
Subglottic Cancer pT3 TNM Finding v6 and v7
}

National Cancer Institute

\section{Source}

National Cancer Institute. Subglottic Cancer pT3 TNM Finding v6 and v7. NCI Thesaurus. Code C64719.

Subg lottic cancer with tumor limited to the larynx with vocal cord fixation. (from AJCC 6th and 7th Eds.) 